\title{
Pengaruh Hot Water Treatment (HWt) dan Perlakuan Pelilinan Dengan EKSTRAK Jahe Terhadap UMUR Simpan CABAi Merah (CAPSiCUM ANNUUm L.) The Influence of Hot Water Treatment (Hwt) and Treatment Wrapping With Ginger Extract Against Age Save Chili Red (Capsicum Annuum L.)
}

\author{
Cicih Sugianti $^{1)}$, Dwi Dian Novita ${ }^{1)}$, Diana Mustika ${ }^{1)}$ \\ ${ }^{1)}$ Jurusan Teknik Pertanian, Fakultas Pertanian, Universitas Lampung, \\ Jl. Soemantri Brojonegoro No. 1 Gedong Meneng Bandar Lampung, Lampung, Indonesia 35145. \\ Email: cicih.sugianti@fp.unila.ac.id
}

\begin{abstract}
ABSTRAK
Penyakit antraknosa salah satu penyakit penting pada tanaman cabai yang disebabkan oleh jamur Colletotrichum capsici. Hot water treatment (HWT) merupakan salah satu teknologi yang dapat diterapkan dalam penanganan pascapanen untuk menekan perkembangan penyakit antraknosa pada cabai merah. Tujuan penelitian ini adalah mempelajari perlakuan pelilinan dengan ekstrak jahe terhadap umur simpan cebe merah. Faktor pertama adalah suhu HWT dengan 3 taraf $\left(45^{\circ} \mathrm{C}, 50^{\circ} \mathrm{C}\right.$, dan $\left.55^{\circ} \mathrm{C}\right)$ selama 15 menit, dan faktor yang kedua adalah pelilinan menggunakan ekstrak jahe dengan 2 taraf (30\% v/v dan 40\%v/v). Hasil penelitian menunjukkan analisis sidik ragam dengan taraf $5 \%$ perlakuan suhu pencelupan berpengaruh nyata terhadap susut bobot, kekerasan, dan kadar air. Faktor konsentrasi ekstrak jahe berpengaruh nyata terhadap kekerasan dan kadar air. Sedangkan interaksi faktor suhu pencelupan dan konsentrasi jahe berpengaruh nyata terhadap kekerasan dan kadar air. Hasil uji lanjut Duncan menunjukkan bahwa perlakuan interaksi terhadap parameter kekerasan, kadar air, dan penampakan cabai merah pada hari ke-18 penyimpanan didapatkan perlakuan terbaik yaitu perlakuan dengan temperatur $45^{\circ} \mathrm{C}$ dan konsentrasi ekstrak jahe $30 \%$.
\end{abstract}

Kata kunci: cabai merah, antraknosa, hot water treatment, pelilinan antimikroba.

\section{ABSTRACT}

Anthracnose disease is one of the dangerous diseases in chili plants caused by Colletotrichum capsici fungus. Hot water treatment (HWT) is one technology that can be applied in post-harvest handling to suppress the spreading of anthracnose disease in red chili plants. The purpose of research was to investigate the effect of temperature and immersion time on hot water treatment, to investigate the effect of anti microbial coating on shelf life on the red chili plants, and to determine the best combination which can maintain the quality of red chili pepper. The first factor was HWT temperature at 3 levels $\left(45^{\circ} \mathrm{C}, 50^{\circ} \mathrm{C}\right.$, and $55^{\circ}$ C) for 15 minutes, and the second factor was contentration of ginger extract treatment at 2 levels $(30 \%$ and $40 \% \mathrm{v} / \mathrm{v}$ ). The results showed the analysis of variance at $5 \%$ of treatment, the immersion temperature significantly affected the weight losses, firmness, and water content. The contentration of ginger extract had a significant effect on the hardness and water content. While the interaction two factors had a significant effect on the hardness and water content. The Duncan's further analysis showed that the best interaction parameters of firmness, water content, and red chili appearance on the 18th day of storage was obtained at $45^{\circ} \mathrm{C}$ and $30 \%$ of gingger extractsconcentration.

Keywords: red chili, anthracnose, hot water treatment, antimicrobial waxing.

Diterima : 7 Maret 2018 ; Disetujui : 25 April 2018; Online Published : -

DOI : $10.24198 /$ jt.vol12n1.5

Pengaruh Hot Water Treatment (Hwt) dan Perlakuan Pelilinan Dengan Ekstrak Jahe Terhadap Umur Simpan Cabai Merah (Capsicum Annuum L.) 


\section{PENDAHULUAN}

Cabai merah (Capsicum annuum L.) merupakan salah satu produk hortikultura yang selalu dibutuhkan oleh masyarakat di Indonesia. Penggunaan cabai merah biasanya sebagai bumbu dapur dan penyedap makanan. Kebutuhan akan cabe terus meningkat dengan semakin meningkatnya jenis dan menu makanan. Menurut BPS Provinsi Lampung (2014), produksi cabai besar Provinsi Lampung tahun 2013 sebesar 35,23 ribu ton, mengalami penurunan Sebesar 7,21 ribu ton $(16,98 \%)$ dibandingkan tahun 2012. Penurunan produksi cabai besar tahun 2013 tersebut terjadi di kabupaten sentra cabai besar yaitu Kabupaten Pesawaran, Lampung Barat dan Tanggamus masing-masing sebesar 7,46 ribu ton, 1,07 ribu ton, dan 510,9 ton dibandingkan tahun 2012.

Menurunnya produksi cabai salah satunya dikarenakan cabai terkena serangan pathogen cendawan penyakit antraknosa. Penyakit ini merupakan salah satu penyakit penting pada tanaman cabai, yang disebabkan oleh jamur Colletotrichum capsici. Menurut laporan Balai Penelitian Hortikultura Lembang (2002) dan Duriat dan Sudorwahadi (1995) dalam Yani (2003), kehilangan hasil pada pertanaman cabai akibat penyakit antraknosa dapat mencapai $14-100 \%$ pada penanaman musim hujan. Suhardi (1992) juga melaporkan bahwa kehilangan hasil buah cabai karena penyakit antraknosa dapat mencapai $100 \%$ bila pengendaliannya kurang tepat, khususnya pada musim hujan. Gejala serangan penyakit pada buah muda dan buah siap panen dapat terus berkembang selama pengangkutan dan penyimpanan (pascapanen) apabila kondisi lingkungan mendukung sehingga diperlukan suatu tindakan pengendalian pasca panen yang efektif dan aman untuk menekan kerugian hasil pasca panen.

Penanganan pascapanen yang baik sangat diperlukan untuk mengendalikan penyakit pascapanen tersebut. Penerapan teknologi juga dipandang sangat penting dalam penanganan pascapanen untuk menekan perkembangan serangan penyakit dan dapat memperpanjang umur simpan, sehingga dapat membantu persediaan cabai dan menekan harga cabai yang terus meningkat. Hot water treatment (HWT) merupakan salah satu teknologi yang dapat diterapkan dalam penanganan pascapanen. Perlakuan ini menggunakan kombinasi suhu dan waktu perendaman pada suhu tertentu. Perlakuan pelilinan menggunakan bahan alami anti mikroba juga dipandang perlu untuk menekan sebaran penyakit yang kita anggap sudah terinvestasi cendawan di lapang. Kusmiadi, R., dkk, (2011) menyatakan bahwa pelapisan pada buah salak menggunakan kombinasi pelilinan antara lilin lebah dengan antimikroba berbahan ekstrak jahe dapat menekan busuk pangkal buah salak pada konsentrasi $30 \%$ atau lebih.

\section{METODOLOGI}

Bahan yang digunakan dalam penelitian ini adalah tanaman cabe diperoleh dari kebun petani di Kalianda, Lampung Selatan (mutu I atau II menurut standar mutu SNI 01-4480-1998), gliserol, ekstrak jahe, dan pektin. Peralatan yang digunakan dalam penelitian adalah: water bath untuk perlakuan HWT, rheometer (model CR-300) untuk mengetahui tingkat kekerasan, timbangan digital (Mettler PM-4800), kamera digital, buret, tabung erlenmeyer dan pipet tetes.

Penelitian ini menggunakan rancangan acak lengkap faktorial. Faktor pertama adalah suhu Hot Water Treatment (HWT) yaitu $45^{\circ} \mathrm{C}$, $50{ }^{\circ} \mathrm{C}$, dan $55{ }^{\circ} \mathrm{C}$ selama 15 menit dan faktor kedua adalah konsentrasi pelilinan dengan konsentrasi ektrak jahe $30 \%$ dan $40 \%$. Persiapan penelitian dilakukan dengan pembersihan dan sortasi sampel cabai untuk menjaga keseragaman sampelnya. Buah cabe tersebut kemudian dibagi dalam sampel untuk kontrol (tanpa perlakuan) dan sampel untuk penerapan Hot Water Treatment (HWT) dan pelilinan anti mikroba dengan total jumlah sampel sesuai dengan kombinasi perlakuannya. Keseluruhan kombinasi perlakuan dalam penelitian ini disimpan pada suhu ruang selama 28 hari. Pengujian dilakukan dengan cara mengidentifikasi 
cendawan yang dapat menyebabkan penyakit pascapanen pada cabai merah. Pengamatan mutu pada cabai dilakukan terhadap parameter susut bobot, vitamin C, kekerasan, dan kadar air.

\section{HASIL DAN PEMBAHASAN}

\section{Cendawan Penyebab Antraknosa}

Antraknosa menjadi masalah utama pada produksi buah tropis, khususnya buah cabai merah besar yang menyebabkan kehilangan nilai ekonomi cukup besar pada buah. Antraknosa disebabkan oleh Colletotrichum spp., yaitu C. capsici, $C$. gloeosporiodes dan C. acutatum (Than et al. 2008a). Namun pada hasil penelitian Fitriani, M (2014) menunjukkan persentase keberadaan $C$. capsici pada buah cabai merah besar lebih dominan (63.89\%) (Tabel 1).

Tabel 1. Persentase keberadaan Colletotrichum spp. pada buah cabai merah

\begin{tabular}{lc}
\hline Spesies & $\begin{array}{l}\text { Persentase keberadaan } \\
\text { Colletotrichum spp. (\%) }\end{array}$ \\
\hline Colletotrichum & 63.89 \\
capsici & \\
C. gloeosporioides & 35.56 \\
C. acutatum & 13.33 \\
\hline
\end{tabular}

Persentase keberadaan Colletotrichum spp. berdasarkan jumlah koloni spesies Colletotrichum dari 9 potongan kulit dan daging buah cabai merah besar pada media PDA yang mengandung $100 \mathrm{mg} / \mathrm{L}$ kloramfeniko

Buah cabai merah besar yang terserang antraknosa menunjukkan gejala berupa timbulnya cekungan yang membesar pada permukaan buah. Pada bagian tengah cekungan terdapat kumpulan titik-titik hitam yang merupakan kelompok aservulus. Serangan $C$. capsici pada buah tidak bersifat toksik terhadap manusia dan hewan, tetapi kerusakan pada buah menjadi pertimbangan untuk kelayakan konsumsi manusia (Nayaka et al. 2009).

\section{Parameter Mutu buah cabai}

\section{Susut Bobot}

Berat rata-rata pada awal penyimpanan cabai merah sebesar 42,543 g, pada akhir penyimpanan yaitu pada hari ke- 20 berat ratarata cabai merah menjadi 39,409 g. Ini menunjukkan persentase susut bobot cabai merah yang berkurang selama penyimpanan 6,653\%. Dari hasil analisis sidik ragam taraf 5\%. Faktor suhu berpengaruh nyata terhadap penurunan susut bobot selama penyimpanan hari ke-10, 14, 16, 18, dan 20. Faktor konsentrasi ektrak jahe pada pelilinan tidak berpengaruh pada susut bobot. Interaksi antara suhu HWT dan konsentrasi ektrak jahe pada pelilinan tidak berpengaruh pada susut bobot. Uji lanjut Duncan pengaruh suhu selama hari yang berpengaruh dapat dilihat pada Tabel 2 .

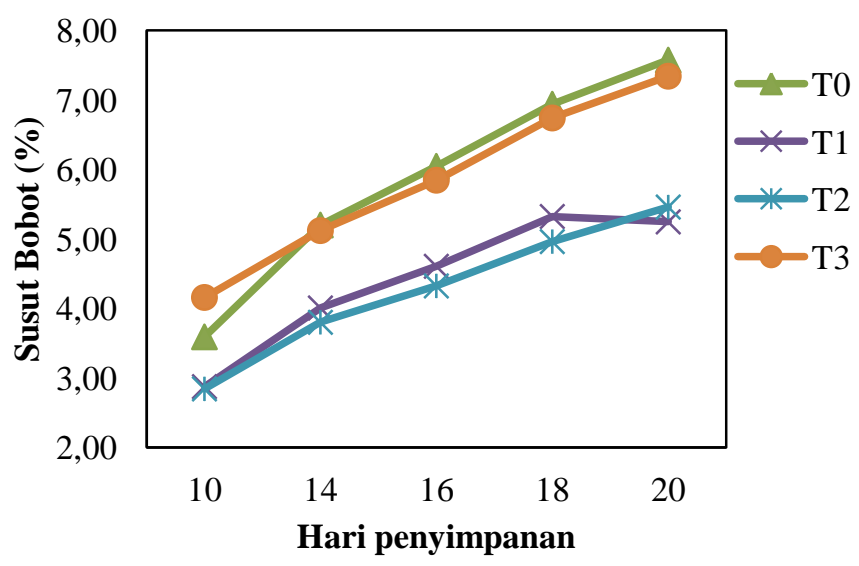

Gambar 1. Grafik peningkatan susut bobot cabai merah selama penyimpanan

Dari Gambar 1 terlihat bahwa hot water treatment pada suhu $50^{\circ} \mathrm{C}$ dapat menekan susut bobot pada cabai merah. Berdasarkan uji lanjut Duncan pengaruh penggunaan suhu $50^{\circ} \mathrm{C}$ dan $55^{\circ} \mathrm{C}$ memiliki pengaruh yang sama selama penyimpanan. Pada penelitian ini, perlakuan HWT dengan suhu pemanasan $55^{\circ} \mathrm{C}$ memang menghindarkan cabai dari penyakit Antraknosa, namun cabai dengan perlakuan tersebut mengalami heat injury, yaitu adanya pelunakan daging buah pada beberapa bagian tertentu dan mengandung banyak air. Kondisi ini kemungkinan dikarenakan waktu pemanasan yang terlalu lama. Menurut Martoredjo (2009), suhu pemanasan yang 
optimal pada produk hortikultura untuk pengendaliannya terhadap penyakit Antraknosa ini adalah dengan perlakuan air panas pada suhu $55^{\circ} \mathrm{C}$ selama 5 menit atau dikombinasikan dengan fungisida hingga suhu dapat diturunkan menjadi $52-53^{\circ} \mathrm{C}$.

Tabel 2. Uji lanjut duncan pengaruh suhu pada penyimpanan cabai merah

\begin{tabular}{lccccc} 
& \multicolumn{5}{c}{ Rata-rata susut bobot hari ke- } \\
\cline { 2 - 6 } Perlakuan & 10 & 14 & 16 & 18 & 20 \\
\hline T0 & $3,589^{\mathrm{ab}}$ & $5,198^{\mathrm{a}}$ & $6,043^{\mathrm{a}}$ & $6,937^{\mathrm{a}}$ & $7,572^{\mathrm{a}}$ \\
\hline T1 & $2,873^{\mathrm{b}}$ & $4,005^{\mathrm{ab}}$ & $4,605^{\mathrm{b}}$ & $5,321^{\mathrm{b}}$ & $5,244^{\mathrm{b}}$ \\
\hline T2 & $2,841^{\mathrm{b}}$ & $3,799^{\mathrm{a}}$ & $4,322^{\mathrm{b}}$ & $4,960^{\mathrm{b}}$ & $5,457^{\mathrm{b}}$ \\
\hline T3 & $4,156^{\mathrm{a}}$ & $5,118^{\mathrm{b}}$ & $5,843^{\mathrm{a}}$ & $6,738^{\mathrm{a}}$ & $7,339^{\mathrm{a}}$ \\
\hline
\end{tabular}

Keterangan: Angka yang diikuti huruf yang sama menunjukkan pengaruh tidak berbeda nyata

\section{Kekerasan}

Nilai kekerasan cabai merah baik di bagian ujung, tengah ataupun pangkal menunjukkan data yang terus menurun dikarenakan adanya kegiatan respirasi pada cabai merah yang dalam prosesnya mengalami penguapan air yang terkandung di dalam buah ke lingkungan. Jadi, jika air di dalam buah berkurang maka cabai akan menjadi lunak. Berkurangnya kandungan air dalam suatu produk pertanian akan mengurangi kerapatan jaringan pada kulit buah sehingga air mudah menguap. Berdasarkan analisis sidik ragam dengan taraf 5\% menunjukkan bahwa faktor suhu HWT, faktor konsentrasi ekstrak jahe, dan interaksi kedua faktor tersebut berpengaruh nyata terhadap kekerasan selama penyimpanan.

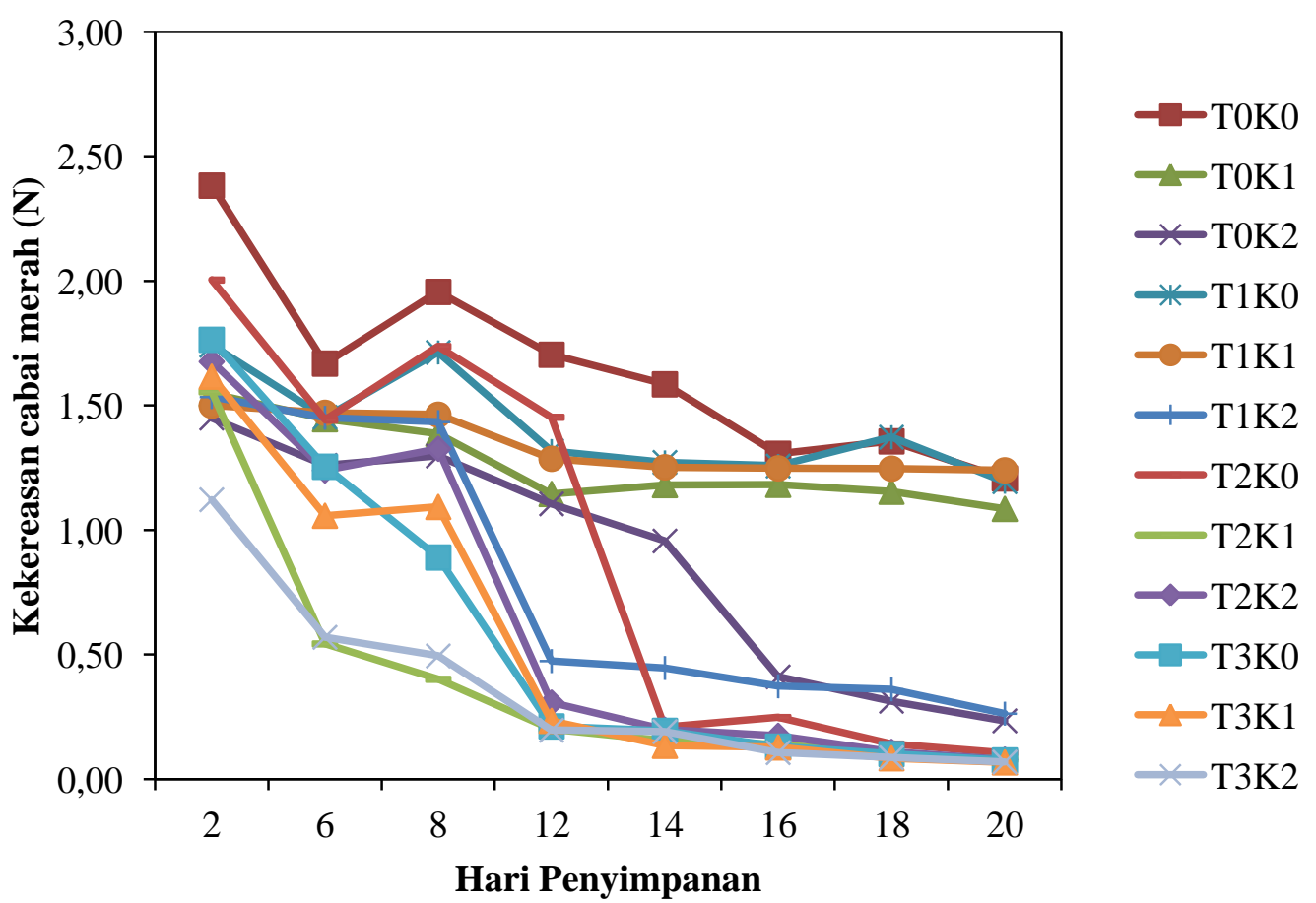

Gambar 2. Grafik kekerasan cabai merah selama penyimpanan

\section{Kadar Air}

Kandungan air pada produk hortikultura merupakan salah satu parameter umur simpan. Hasil analisis sidik ragam taraf $5 \%$ menunjukkan bahwa faktor suhu berpengaruh terhadap kadar air pada hari penyimpanan ke-10, konsentrasi ektrak jahe berpengaruh terhadap kadar air pada hari penyimpanan ke-8, dan interaksi kedua faktor berpengaruh terhadap kadar air pada hari penyimpanan ke-12 dan 18. Hasil uji lanjut interaksi pada penyimpanan ke-12 dan 18 terdapat pada Tabel 3. 
Tabel 3. Uji lanjut Duncan hasil interaksi perlakuan suhu dan konsentrasi ekstrak jahe pada pelilinan terhadap kadar air

\begin{tabular}{lcc}
\hline \multirow{2}{*}{ Perlakuan } & \multicolumn{2}{c}{ Hari Penyimpanan ke- } \\
\cline { 2 - 3 } & 12 & 18 \\
\hline T0K0 & $76,014^{\mathrm{d}}$ & $78,773^{\mathrm{b}}$ \\
\hline T0K1 & $78,936^{\mathrm{ab}}$ & $80,018^{\mathrm{ab}}$ \\
\hline T0K2 & $79,163^{\mathrm{ab}}$ & $79,093^{\mathrm{b}}$ \\
\hline T1K0 & $79,789^{\mathrm{a}}$ & $80,756^{\mathrm{ab}}$ \\
\hline T1K1 & $77,060^{\mathrm{cd}}$ & $78,452^{\mathrm{b}}$ \\
\hline T1K2 & $80,214^{\mathrm{a}}$ & $80,859^{\mathrm{ad}}$ \\
\hline T2K0 & $80,148^{\mathrm{a}}$ & $80,703^{\mathrm{ab}}$ \\
\hline T2K1 & $78,491^{\mathrm{abc}}$ & $78,530^{\mathrm{b}}$ \\
\hline T2K2 & $79,850^{\mathrm{a}}$ & $83,462^{\mathrm{a}}$ \\
\hline T3K0 & $77,752^{\mathrm{bcd}}$ & $79,680^{\mathrm{b}}$ \\
\hline T3K1 & $78,986^{\mathrm{ab}}$ & $81,827^{\mathrm{b}}$ \\
\hline T3K2 & $80,273^{\mathrm{a}}$ & $78,876^{\mathrm{b}}$ \\
\hline Keterangan
\end{tabular}

Keterangan: Angka yang diikuti huruf yang sama pada kolom yang sama menunjukkan pengaruh tidak berbeda nyata

Pelapisan lilin menyebabkan transpirasi berjalan lambat, sehingga kadar air bebas yang terdapat di dalam buah maupun hasil respirasi dapat dipertahankan. Transpirasi menyebabkan buah kehilangan air sehingga berpengaruh terhadap kesegaran dan kerenyahan buah. Semakin kecil transpirasi maka buah akan terlihat semakin segar dan sebaliknya. Kadar air merupakan faktor penting dalam penyimpanan, terutama pada penyimpanan bahan-bahan segar, karena kadar air akan berpengaruh pada konsistensi bahan dan berpengaruh terhadap keawetan bahan pangan tersebut. (Winarno et al., 1997). Setelah pemetikan buah masih mempunyai kadar air yang tinggi kemudian akan terus menurun sampai pemasakan (Pantastico, 1986).

Berdasarkan parameter mutu pengamatan yang diamati meliputi susut bobot, kekerasan, vitamin $\mathrm{C}$, kadar air, dan warna dapat dicari perlakuan terbaik untuk pada penelitian ini. Perlakuan terbaik dilihat dari parameter yang memiliki interaksi yang berpengaruh terhadap parameter tersebut. Interaksi yang berpengaruh pada penelitian ini dilihat dari nilai-nilai interaksi. Hasil analisis uji lanjut Duncan interaksi pada pengamatan kekerasan dan kadar air pada penyimpanan hari ke-18 dapat dilihat pada Tabel 4.

Tabel 4. Hasil uji lanjut interaksi parameter kekerasan dan kadar air pada hari penyimpanan ke-18.

\begin{tabular}{lcc}
\hline \multirow{2}{*}{ Perlakuan } & \multicolumn{2}{c}{ Hari Penyimpanan ke-18 } \\
\cline { 2 - 3 } & Kekerasan & Kadar Air \\
\hline T0K0 & $1,357^{\mathrm{a}}$ & $78,773^{\mathrm{b}}$ \\
\hline T0K1 & $1,154^{\mathrm{b}}$ & $80,018^{\mathrm{ab}}$ \\
\hline T0K2 & $0,313^{\mathrm{c}}$ & $79,093^{\mathrm{b}}$ \\
\hline T1K0 & $1,373^{\mathrm{a}}$ & $80,756^{\mathrm{ab}}$ \\
\hline T1K1 & $1,247^{\mathrm{a}}$ & $78,452^{\mathrm{b}}$ \\
\hline T1K2 & $0,361^{\mathrm{c}}$ & $80,859^{\mathrm{ad}}$ \\
\hline T2K0 & $0,141^{\mathrm{d}}$ & $80,703^{\mathrm{ab}}$ \\
\hline T2K1 & $0,101^{\mathrm{d}}$ & $78,530^{\mathrm{b}}$ \\
\hline T2K2 & $0,110^{\mathrm{d}}$ & $83,462^{\mathrm{a}}$ \\
\hline T3K0 & $0,101^{\mathrm{d}}$ & $79,680^{\mathrm{b}}$ \\
\hline T3K1 & $0,084^{\mathrm{d}}$ & $81,827^{\mathrm{b}}$ \\
\hline T3K2 & $0,087^{\mathrm{d}}$ & $78,876^{\mathrm{b}}$ \\
\hline Keterangan
\end{tabular}

Keterangan: Angka yang diikuti huruf yang sama pada kolom yang sama menunjukkan pengaruh tidak berbeda nyata

Berdasarkan parameter kekerasan dan kadar air perlakuan yang terbaik dipilih TOK0 dan T1K1. Perbandingan penampakan pada hari ke 18 terlihat bahwa penampakan cabai merah yang diberi perlakuan T1K1 lebih baik dibandingkan dengan perlakuan TOK0. Sehingga dapat disimpulkan dalam penerapan kombinasi perlakuan HWT dan pelilinan menggunakan ektrak jahe di dapat pada perlakuan $\mathrm{T} 1 \mathrm{~K} 1$ berdasarkan parameter kekerasan, kadar air, dan penampakan cabai merah tersebut. 


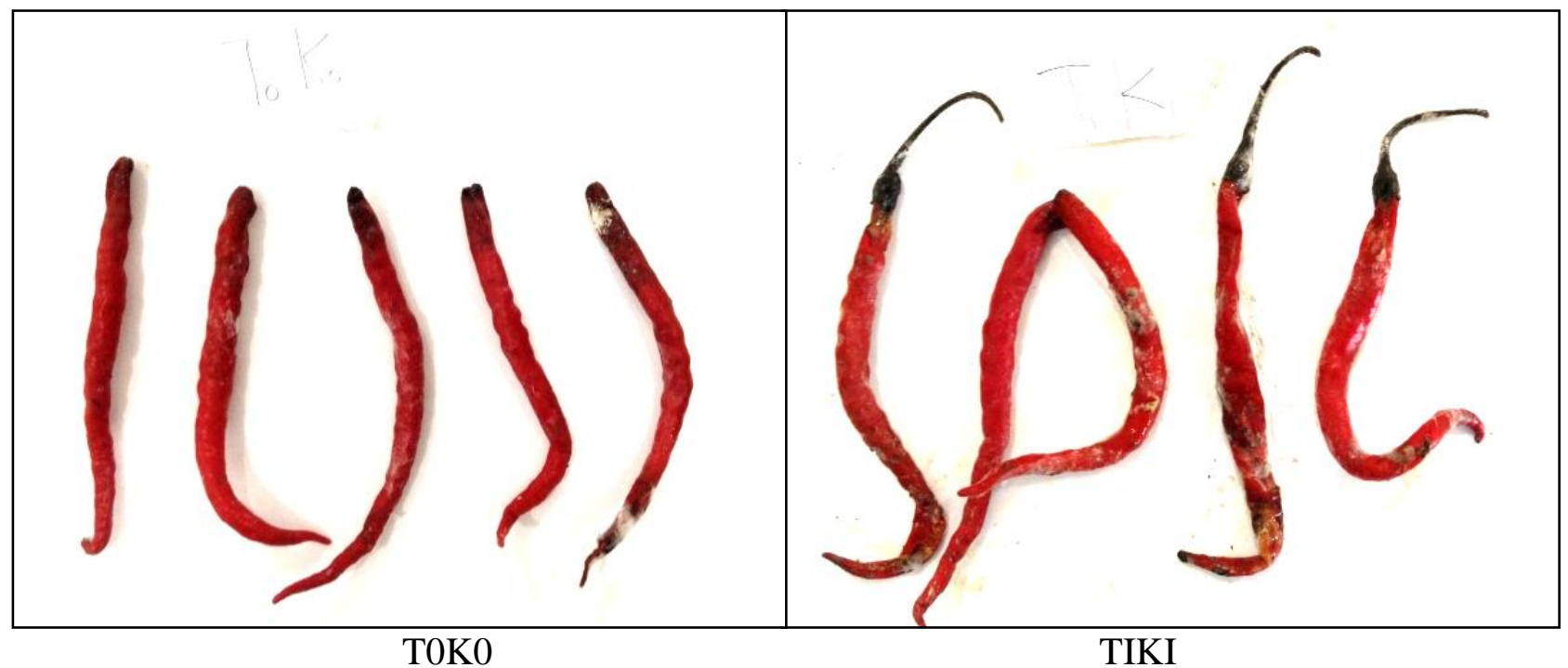

Gambar 3. Penampakan pada penyimpanan ke 18 cabai merah

\section{KESIMPULAN DAN SARAN}

\section{Kesimpulan}

Hasil identifikasi cendawan yang menyebabkan penyakit antraknosa pada cabai merah adalah Colletotrichum capsici, $C$. gloeosporioides, and C. Acutatum. Berdasarkan analisis sidik ragam pada taraf 5\% menunjukkan pengaruh suhu HWT berpengaruh terhadap susut bobot, kekerasan, dan kadar air. Konsentrasi ekstrak jahe berpengaruh terhadap kekerasan dan kadar air. Sedangkan interaksi kedua factor berpengaruh terhadap kekerasan dan kadar air. Hasil uji lanjut Duncan menunjukkan bahwa interaksi perlakuan $\mathrm{HWT} 45^{\circ} \mathrm{C}$ dan konsentrasi ekstrak jahe $30 \%$ berpengaruh sangat nyata terhadap parameter kekerasan dan kadar air terlihat pada hari ke-18 penyimpanan.

\section{Saran}

Saran dari penelitian ini adalah perlu dilakukan penelitian yang melibatkan perbedaan suhu penyimpanan terhadap perkembangan cendawan Colletotrichum capsici.

\section{UCAPAN TERIMAKASIH}

Tim peneliti mengucapkan terimakasih kepada semua pihak jurusan Teknik Pertanian dan LPPM Universitas lampung yang telah mendukung pembiayaan melalui DIPA BLU JUNIOR Tahun Anggaran 2015 dengan Nomor Kontrak 550/UN26/8/LPPM/2015.

\section{DAFTAR PUSTAKA}

BPS Provinsi Lampung . 2014. Berita Resmi Statistik BPS Provinsi Lampung No 13/08/18/Th.II, 4 Agustus 2014.

Fitriani, M. 2014. Mikobiota pada buah cabai: pengaruhnya Terhadap Colletotrichum capsici, cendawan penyebab antraknosa. Skripsi. FMIPA IPB, Bogor.

Kader AA. 1992. Postharvest Biology and Technology of Horticultural Crop. Publication 3311. Davis: University of California-USA.

Kusmiadi, R. 2011. Kajian Efikasi Ekstrak Rimpang Jahe Dan Kunyit Sebagai Upaya Untuk Memperpanjang Umur Simpan Buah Salak Pondoh Akibat Serangan Cendawan. Tesis. Pascasarjana IPB. Bogor.

Susanto. 1994. Fisiologi dan Teknologi Pasca

Panen. Yogyakarta: Akademika. 
Winarno FG. 2002. Fisiologi Lepas Panen Produk Hortikultura. Bogor (ID): MBrio Pr.

Yani, A. 2003. Pengendalian Cendawan Pascapanen Colletotrichum capsici Penyebab Penyakit Antraknosa Pada Buah Cabai (Capsicum annum L). Balai Pengkajian. Teknologi Pertanian Lampung. Prosiding Lokakarya
Nasional Pengembangan Pertanian Lahan Kering. http//.litbang.deptan.go.id/pustaka/Alfi.p df.

Zong Y, Liu J, Li B, Qin G, Tian S. 2010. Effects of yeast antagonists in combination with hot water treatment on postharvest diseases of tomato fruit. Biological Control 54 (2010): 316-321. 